\title{
PUTUSAN HAKIM: MENUJU RASIONALITAS HUKUM REFLEKSIF DALAM PENEGAKAN HUKUM
}

\author{
Oleh: \\ HM. Soerya Respationo \\ (Fakultas Hukum Universitas Batam, Batam) \\ dan \\ M. Guntur Hamzah \\ (Fakultas Hukum Universitas Hasanuddin, Makassar) \\ Email:
}

\begin{abstract}
Abstrak
Penegakan hukum tidak bekerja dalam ruang yang hampa sosial. Penegakan hukum senantiasa berinteraksi dengan dinamika masyarakat (external dynamics) dan dinamika dalam hukum itu sendiri (internal dynamics). Oleh karena itu, putusan hakim hendaknya merefleksikan kedua dinamika itu dengan cara mengkonstatir hubungan antara fakta, norma, moral, dan doktrin hukum dalam pertimbangan putusan hakim -baik secara sendiri-sendiri, maupun bersama-sangat terkait atau korelatif satu sama lain.Pola putusan hakim, termasuk penegakan hukumnya yang berlangsung saat ini masih didominasi tipe rasionalitas hukum formal. Ke depan -dalam rangka "good court governance"-pengembanan hukum praktis hendaknya di arahkan ke tipe rasionalitas refleksif, minimal diupayakan menggeser pola hubungan tersebut dari tipe rasionalitas formal ke rasionalitas substantif dan pada saatnya ke arah tipe rasionalitas hukum refkleksif.
\end{abstract}

Key Words: Putusan Hakim, Rasionalitas Hukum Refleksif, Penegakan Hukum

\begin{abstract}
Law enforcement does not work in a social vacuum of space. Law enforcement continues to interact with the dynamics community (external dynamics) and the dynamics within the law itself (internal dynamics ). Therefore, the judge's decision should reflect both the dynamics of the relationship between facts mengkonstatir way, norms, moral, and legal doctrine in consideration of the judge's decision either individually, or collectively a very related or the same correlative lain.pola verdict, including the enforcement of the present day is still dominated by the type of formal legal rationality. Forward - in the context of "good governance court " - developing of practical law should be directed to the type of reflexive rationality, at least attempted to shift the pattern of the relationships of all types of formal rationality and substantive rationality in time towards the type of legal rationality refkleksif .
\end{abstract}

Key Words : Judgment, Rationality Reflexive Law , Law Enforcement

\section{A. Pendahuluan}

Putusan hakim (vonnis) sejatinya diadakan untuk menyelesaikan suatu perkara atau sengketa dalam bingkai tegaknya hukum dan keadilan. Para pencari keadilan (the seeker of justice) tentu saja berharap bahwa putusan seorang hakim benarbenar memenuhi rasa keadilan masyarakat (sense of justice). Antara undang - undang dengan Hakim / pengadilan, terdapat hubungan yang erat dan harmonis antara satu dengan lainnya. Dalam mencarikan hukum yang tepat dalam rangka menyelesaikan suatu perkara yang dihadapkan kepadanya tersebut, Hakim yang bersangkutan harus melakukan Penemuan Hukum.

Menurut Mertokusumo, ada beberapa istilah yang berkaitan dengan Penemuan Hukum, yaitu :

1. Pelaksanaan Hukum

2. Penerapan Hukum

3. Pembentukan Hukum, atau

4. Penciptaan Hukum

Pelaksanaan hukum dapat diartikan menjalankan hukum tanpa adanya sengketa atau pelanggaran. Penerapan hukum berarti 
menerapkan ketentuan peraturan perundang undangan yang abstrak sifatnya pada peristiwa konkrit. Pembentukan hukum adalah merumuskan peraturan - peraturan yang berlaku umum bagi setiap orang. Sedangkan penciptaan hukum ini memberikan kesan bahwa hukum itu hanya peraturan tertulis saja, sehingga kalau tidak diatur dalam peraturan tertulis, maka kewajiban hakimlah untuk menciptakannya.Namun mewujudkan putusan hakim yang sesuai dengan rasa keadilan masyarakat ternyata tidak mudah. Bahkan dalam beberapa putusan pengadilan justru bermasalah dan menimbulkan kontroversi di tengah masyarakat.

Apabila kontroversi itu disebabkan oleh penolakan atau ketidakberterimaan salah satu pihak yang berperkara tentu saja masih dapat dimaklumi, karena pihak yang kalah seringkali merasa tidak puas, sebaliknya pihak yang menang menilai putusan hakim yang memenangkannya adalah putusan yang adil. Akan tetapi, sering kali putusan hakim menimbulkan kontroversi di masyarakat, bahkan penolakan karena putusan pengadilan bertolakbelakang dengan akal sehat atau pemahaman masyarakat karena ketidakkoherensian antara fakta, norma, moral, dan doktrin hukum dalam pertimbangan putusan hakim.

Ditinjau dari ajaran pemisahan kekuasaan melalui doktrin "Trias Politika" sebagaimana diketengahkan oleh Emmanuel Kant maupun Montesquieu dan dikembangkan oleh John Locke melalui ajaran "Separation of Power" yaitu :

"There can no be liberty when the legislative and executive power are jointed in the same persons or body of lords because it to be feared that the monarch or body will make tyrannical laws to be administered in tyrannical way. Nor is there any liberty if the judicial power is not separated from the legislative and executive power."

bahwa tidak ada kemerdekaan apabila kekuasaan yudikatif, legislatif, dan eksekutif berada dalam satu tangan atau badan. Apabila kekuasaan-kekuasaan tersebut berada di satu tangan akan menimbulkan suatu "tirani". Konsep pemikiran masyarakat yang bebas diawali dengan pemisahan kekuasaan antara kekuasaan legislatif dengan eksekutif maupun yudikatif dengan kekuasaan legislatif dan eksekutif.

Terhadap putusan hakim yang tidak koheren jelas mencerminkan bahwa pengembanan hukum praktis berlangsung tidak normal (abnormal). Dituntut bagi seorang Hakim untuk mewujudkan putusan benar dan adil yang sangat didambakan sepenuhnya oleh para pencari keadilan, perpaduan sifat berperilaku bagi seorang Hakim yang sekaligus juga penegak hukum berupa sifat - sifat utama yang diajarkan dan diwariskan oleh para leluhur bangsa Indonesia. Putusan Hakim sebagai Penemuan Hukum, berati berkewajiban merumuskan pertimbangan-pertimbangannya tidak hanya berdasarkan ilmu hukum dengan pelbagai ilmu-ilmu bantuannya, tetapi juga melibatkan filsafat hukum dan teori hukum, lebih-lebih apabila berhadapan dengan perkara - perkara yang secara mendasar benar - benar menyentuh hati nurani.

Dalam prinsip berpikir sistem, emergent itu dipahami sebagai produk yang lahir dari pola interaksi antarkomponen yang terdapat dalam sebuah sistem. Jika dasar dan pola interaksi antarkomponen dalam sistem itu baik, maka dia akan melahirkan emergent yang baik, demikian pula sebaliknya (Hayyan UI Haq, 2005). Dalam kaitannya dengan pengembanan hukum, putusan hakim yang tidak koheren merupakan produk (emergent) yang abnormal. Ini berarti, putusan lahir dari seluruh rangkaian aktivitas pengembanan hukum yang juga abnormal. Putusan Hakim adalah Penemuan Hukum dalam artian khusus mengandung pengertian proses dan karya yang dilakukan oleh Hakim, yang menetapkan benar dan tidak benar menurut hukum dalam situasi konkrit, yang diujikan kepada hati nurani. Dalam rangka meningkatkan peran Hakim untuk mewujudkan putusan yang benar dan adil, maka dituntut bagi seorang Hakim untuk menerapkan metode pendekatan Penemuan Hukum, yang dapat memenuhi rasa keadilan masyarakat.

Masalah penegakan hukum (law enforcement) sesungguhnya bukanlah persoalan yang berdiri sendiri. Ada rangkaian yang saling mempengaruhi sehingga melahirkan putusan hakim yang bermasalah. Ketua Komisi Yudisial Eman Suparman, menengarai bahwa selama ini memang terdapat perbedaan penafsiran atas beberapa bagian Kode Etik dan Pedoman Perilaku Hakim. KY menganggap ada hubungan kuat antara perilaku dengan putusan hakim, utamanya kepatuhan penerapan hukumacara dan komprehensifnya hakim melihat fakta persidangan. Mahkamah Agung berpendapat KY tidak berwenang menilai putusan hakim. Namun menurut Eman Suparman, KY memang tidak menilai putusan hakim. Putusan hakim hanyalah pintu masuk untuk mendeteksi adanya pelanggaran KEPPH (Dinal Fedrian, 2012).

Data KY menunjukkan bahwa sejak Januari hingga Juni 2012, KY telah menerima 731 pengaduan. Dari jumlah tersebut sudah 161 pengaduan yang ditindaklanjuti. Rinciannya sampai pemeriksaan hakim (6), pemeriksaan 
pelapor/saksi (39), klarifikasi surat/diteruskan ke instansi lain (110), investigasi (2), dan permintaan alat bukti (4). Dari laporan itu terungkap 14 hakim direkomendasikan Komisi Yudisial untuk dijatuhi sanksi (Komisi Yudisial, 2012).

Dalam beberapa kasus, MA tidak bisa melaksanakan seluruh rekomendasi KY dengan alasan beberapa rekomendasi terkait dengan kasalahan hakim yang masuk kategori teknis yudisial. Padahal, bidang teknis yudisial ini justru berpotensi digunakan oleh hakim "nakal" untuk memainkan perkara. Modus yang biasa dipakai hakim untuk memainkan perkara dalam tataran teknis yudisial itu misalnya tidak mencantumkan fakta hukum dalam pertimbangan putusan, atau memanipulasi tafsir hukum sehingga suatu perkara bisa mendapat putusan bebas atau putusan minimal (Waspada online 9 Desember 2009).

Salah satu hal yang sampai saat ini masih menjadi kontroversi besar adalah perihal apakah frasa "...wewenang lain dalam rangka menjaga dan menegakkan kehormatan, keluhuran martabat, serta perilaku hakim " berarti juga memperbolehkan KY dalam rangka pengawasan untuk melakukan pemeriksaan terhadap putusanputusan

Persoalan putusan hakim yang tidak koheren dengan fakta hukum dan manipulasi tafsir hukum inilah yang menjadi salah satu sorotan paper ini. Bahkan dalam konteks law enforcement persoalan ini jauh lebih kompleks. Oleh karena itu, putusan hakim harus diletakkan dalam konteks kekoherensiannya dengan aspek fakta hukum, norma, moral, dan doktrin hukum. Namun bagaimana hubungan antara fakta, norma, moral dan doktrin dalam pertimbangan putusan hakim dalam konteks penegakan hukum? Penulis mencoba menjelaskan dalam dua aspek, yaitu (1) hubungan kedudukan dan peranannya terhadap putusan hakim, dan (2) hubungan berdasarkan tipe rasionalitas hukum.

\section{B. Hubungan Berdasarkan Kedudukan dan Peranannya Terhadap Putusan Hakim}

\section{Putusan Hakim dan Fakta Hukum}

Setiap putusan hakim harus berdasarkan fakta yang jelas. Fakta memegang peranan penting dalam setiap putusan hakim. Bahkan fakta hukum merupakan "conditio sine qua non" bagi terwujudnya putusan yang adil. Oleh karena itu, dalam memutuskan perkara pasti membutuhkan fakta hukum dari suatu perkara. Putusan hakim akan adil jika berdasarkan fakta yang benar. Dengan demikian, hukum tidak akan bisa diputus dengan adil jika fakta hukum tidak ada.

Dalam kaitan ini, sangat menarik tanggapan Ketua KY Busyro Muqoddas yang menyatakan bahwa, jika hakim telah menyampingkan fakta persidangan, fakta saksi, bukti lain, dan fakta pembelaan, itu berarti hakim telah melakukan kesalahan fatal. "Fakta-fakta itu harus dimuat dalam pertimbangan hakim," secara normatif putusan hakim seharusnya memperhatikan fakta persidangan, baik itu fakta saksi, bukti, maupun fakta pembelaan (Media Indonesia, 2 Februari 2012).

Berlandaskan platform sebagaimana terurai tersebut, maka tipologisasi penemuan hukum menurut ajaran G. J. Wiarda adalah tepat, padat dan benar sebagaimana dipersonifikasikan pada tiga wujud ( trimatra penemuan hukum ) sebagai berikut :

1. Hakim sebagai corong Undang - undang ;

2. Hakim sebagai penterjemah Undang undang / Hukum ;

3. Hakim yang menimbang dan memutuskan demi dan menurut keadilan.

Dengan demikian sesuai hal- hal tersebut terlukiskan pula hakekat, tugas dan fungsi Hakim yaitu melakukan penemuan hukum dengan hasil keputusan hati nurani terhadap perkara yang diajukan kepadanya untuk diperiksa dan diadili.

Dengan demikian, fakta hukum merupakan sesuatu yang sangat fundamental dalam putusan hakim karena merefleksikan tindakan manusia, keadaan atau peristiwa yang menjadi sorotan utama dalam proses peradilan. Fakta hukum merupakan intrumen bagi hakim dalam meneguhkan asumsiasumsi menjadi kenyataan(to be reality). Bahkan sesungguhnya, asas praduga tidak bersalah (presumption of innocence) yang menjadi salah satu asas terpenting dalam hukum acara sangat terkait dengan fakta, karena sebelum fakta "berbicara" yang kemudian menjelma dalam putusan hakim maka seseorang dianggap tidak/belum bersalah.

Dalam konteks hubungan fakta hukum dengan putusan hakim, maka jelas bahwa fakta hukum yang membuat dugaan-dugaan atau dakwaan-dakwaan pihak penutut umum dalam perkara pidana menjadi terbukti atai tidak terbukti. Demikian pula dalam perkara perdata dan tata usaha negara, fakta hukum 
terjelma dalam pembuktian atas gugatan penggugat dan bantahan tergugat dalam proses peradilan. Fakta hukum merupakan sisi "das sein" sebuah putusan hakim. Tanpa fakta hukum, maka sesungguhnya tidak ada putusan hakim (there are not facts, no judge's decision).

\section{Putusan Hakim dan Norma Hukum}

Setiap putusan hakim harus berlandaskan norma hukum yang jelas. Norma adalah pernyataan yang menekankan aspek "seharusnya" atau "das solen", dengan menyertakan beberapa peraturan tentang apa yang harus dilakukan. Norma juga diartikan sebagai patokan perilaku dalam suatu kelompok masyarakat tertentu yang pada umumnya berupa perintah dan larangan.Untuk dapat menjalankan fungsinya yang demikian itu, tentu saja norma harus mempunyai kekuatan hukum yang bersifat memaksa. Paksaan ini tertuju kepada para anggota masyarakat dengan tujuan untuk mematuhinya (Satjipto Rahardjo, 2000).

Norma hukum merupakan bagian dari norma sosial. Dalam hubungan ini, J.J.H. Bruggink menegaskan bahwa norma hukum (rechtsnorm) menunjuk pada proposisi dari suatu aturan hukum (rechtsregel), sebab arti dari sutau aturan hukum itu harus ditautkan pada isi normanya, dengan catatan: pertama, isi norma menentukan wilayah penerapannya. Kedua, isi kaidah berbanding terbalik wilayah penerapannya (J.J.H. Bruggink, 2006).

Lebih lanjut menurut Bruggink, norma atau kaidah-kaidah hukum memiliki beragam bentuk dan jenisnya, antara lain kaidah perilaku mencakup perintah, larangan, izin dan dispensasi, serta kaidah sanksi. Meta kaidah yakni berkenaan dengan kaidah perilaku mencakup kaidah pengakuan, kaidah perubahan, kaidah kewenangan, kaidah definisi, dan kaidah penilaian atau yang lebih dikenal dengan nama asas-asas hukum.

Dalam konteks putusan hakim, maka kaidah atau norma hukum memegang peranan sebagai pedoman(leiding)dan instrumen pengujian (toetsingrecht) bagi aktivitas manusia atau seseorang yang diatur dalam ruang lingkup peraturan perundangundangan yang berlaku. Sifat norma hukum merupakan sisi "das sollen" sebuah putusan hakim. Tanpa memperhatikan norma hukum, maka sesungguhnya putusan hakim tersebut bersifat sewenang-wenang.

\section{Putusan Hakim dan Moral}

Setiap putusan hakim seyogianya merefleksikan pertimbangan moral. Moral adalah istilah manusia menyebut ke manusia atau orang lainnya dalam tindakan yang mempunyai nilai positif. Moral adalah sikap dasar yang harus dimiliki oleh seorang manusia jika ia ingin dihormati oleh sesamanya. la merupakan kondisi pikiran, perasaan, ucapan dan perilaku manusia yang terkait dengan nilai-nilai baik dan buruk. Dengan demikian, Moral merupakan nilai keabsolutan alam kehidupan bermasyarakat secara utuh.

Pada dasarnya, kedudukan moral dalam teori hukum termasuk bagian dari norma atau kaidah hukum dalam arti luas. Tetapi -dalam arti sempit-kaidah hukum dapat dibedakan dengan kaidah moral. Perbedaan antara kaidah hukum dan kaidah moral mengacu pada kualitas perbuatan manusia yang dilakukan. Moralitas suatu perbuatan menyatakan bahwa perbuatan itu sesuai dengan kaidah moral (morele wetten). Sedang legalitas suatu perbuatan menyatakan bahwa perbuatan itu sesuai dengan kaidah hukum (juridische wetten) (J.JH. Bruggink, 2006).

Dalam konteks putusan hakim, maka kedudukan moral memegang peranan sebagai pengendali (sturende)dan refleksi motivasi diri seorang hakim dalam proses pengambilan putusan. Putusan hakim yang lahir dari proses kontemplasi moral baik dari segi lahiriah maupun batiniahakan menghasilkan putusan hakim yang adil, karena putusan hakim yang berbasis moral tentu saja telah koheren dengan pertimbangan fakta, norma, doktrin baik dari segi lahiriah maupun batiniah serta lebih komprehensif dan utuh. Sebaliknya, jika putusan hakim tidak dilandasi pertimbangan moral, maka putusan hakim tersebut gagal dari aspek pertanggungjawaban moral, sehingga putusan hakim demikian itu sesungguhnya menjauh dari rasa keadilan masyarakat.

\section{Putusan Hakim dan doktrin Hukum}

Setiap putusan hakim sedapat mungkin paralel dengan pandangan para ahli (doktrin). Doktrin adalah pendapat ahli hukum atau pakar yang bereputasi di bidang hukum yang biasanya dijadikan hakim sebagai pedoman dalam memperkaya argumentasi hakim dalam mengambil putusan. Tentu saja, tidak semua pandangan sarjana hukum yang dapat masuk dalam kualifikasi doktrin, melainkan 
hanya pakar-pakar yang diakui keahliannya oleh masyarakat.

Bukan hanya dalam pergaulan hukum nasional berlaku doktrin sebagai sumber hukum, melainkan juga dalam pergaulan hukum internasional. Bahkan, dalam hukum internasional, doktrin merupakan sumber hukum yang paling penting. Sebagai contoh, Mahkamah Internasional di Den Haag, Nederland, mengakui pentingnya doktrin, terlihat dalam Pasal 38 ayat 1 Statute of Internasional court of Justice, yang menunjuk "teaching of the must highly qualifed publicists" yang tidak lain adalah doktrin (Achmad ali, 2008).

Dalam konteks putusan hakim, maka kedudukan doktrin hukum memegang peranan sebagai jembatan (bridge) dan cahaya penerang (shining light). Dalam kedudukan sebagai jembatan, doktrin hukum menghubungkan antara dunia teoretik dan praktik, serta antara "das sollen" dan "das sein". Sedang dalam kedudukannya sebagai cahaya penerang, doktrin hukum memberi pencerahan dan kualitas argumentasi dalam setiap pertimbangan putusan hakim. Dengan demikian, putusan hakim yang memuat doktrin hukum akan lebih berbobot dan mencerahkan.Sebaliknya,jika putusan hakim tidak sejalan dengan doktrin hukum maka sesungguhnya putusan hakim tersebut kehilangan arah (lose of direction).

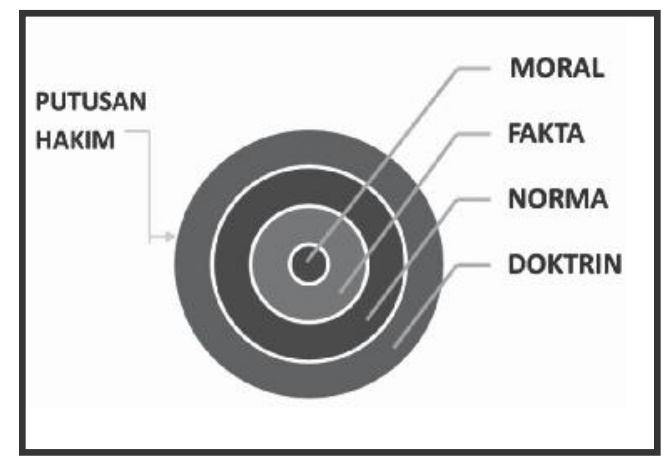

C. Hubungan Berdasarkan Tipe Rasionalitas Hukum

Putusan hakim adalah suatu pernyataan hakim -sebagai pejabat negara-yang diberi wewenang untuk itu, diucapkan dipersidangan dan bertujuan untuk mengakhiri atau menyelesaikan suatu perkara atau sengketa antara para pihak. Bukan hanya yang diucapkan saja yang disebut putusan, melainkan juga pernyataan yang dituangkan dalam bentuk tertulis dan kemudian diucapkan oleh hakim dipersidangan. Sebuah konsep putusan (tertulis) tidak mempunyai kekuatan sebagai putusan sebelum diucapkan di persidangan oleh hakim. Putusan yang diucapkan dipersidangan tidak boleh berbeda dengan yang tertulis (vonnis) (Sudikno Mertokusumo, 2008).

Untuk menjelaskan hubungan antara putusan hakim (vonnis) dengan fakta, norma, moral dan doktrin dari perspektif rasionalitas hukum, penulis menggunakan konsep rasionalitas hukum Gunther Teubner. Menurut Teubner, ada 3 (tiga) tipe rasionalitas hukum yaitu (Gunther Teubner, 1983:
a. Rasionalitas formal
b. Rasionalitas substantif
c. Rasionalitas refleksif

Tipe rasionalitas hukum (formal) berorientasi pada ketaatan hukum formal. Sedangkan rasionalitas hukum (substantif) berorientasi pada hasil dan tujuan. Adapun tipe rasionalitas hukum (refleksif) berorientasi pada proses dan motif dibalik proses-proses tersebut.

Dengan menggunakan konsep rasionalitas hukum model Gunther Teubner di atas, maka hubungan antara fakta, norma, moral dan doktrin dalam pertimbangan putusan hakim dapat digambarkan dalam tabel/matriks sebagai berikut:

Tabel: Hubungan Berdasarkan Tipe Rasionalitas Hukum

\begin{tabular}{|c|c|c|c|}
\hline \multirow{2}{*}{ dimensi } & \multicolumn{3}{|c|}{ Tipe Rasionalitas Hukum } \\
\hline & Formal & Substantif & Refleksif \\
\hline FAKTA & $\begin{array}{ll}\text { - } & \text { Ketaatan pada hukum } \\
& \text { formal. } \\
\text { - } & \text { Pembuktian lebih me- } \\
& \text { nekankan aspek formal. } \\
\text { - } \quad \text { Kebenaran formal. } \\
\text { - } \quad \text { Hakim sbg terompet } \\
\text { UU. }\end{array}$ & $\begin{array}{ll}\text { - } & \text { Ketaatan pada } \\
\text { substansi hukum. } \\
\text { - } \quad \text { Pembuktian lebih } \\
\text { menekankan aspek } \\
\text { substansi. } \\
\text { - } \text { Kebenaran materil. }\end{array}$ & $\begin{array}{l}\text { - } \quad \text { Ketaatan pada substansi } \\
\text { hukum. } \\
\text { - } \quad \text { Pembuktian lebih menekankan } \\
\text { koherensi aspek formal, } \\
\text { materil, dan proses-proses yg } \\
\text { menyertainya. } \\
\text { - Kebenaran refleksif. }\end{array}$ \\
\hline
\end{tabular}




\begin{tabular}{|c|c|c|c|}
\hline NORMA & 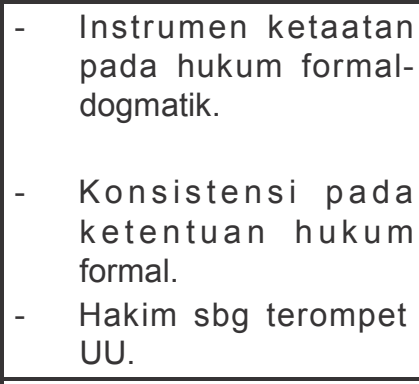 & $\begin{array}{l}\text { - Instrumen ketaatan } \\
\text { pada substansi } \\
\text { hukum. } \\
\text { - Diskresi sesuai } \\
\text { substansi hukum. } \\
\text { - Hakim tidak sekedar } \\
\text { terompet UU. }\end{array}$ & 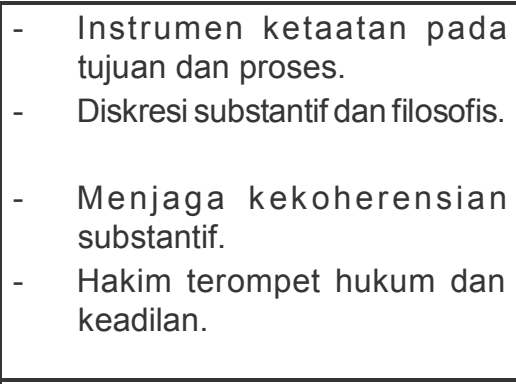 \\
\hline MORAL & $\begin{array}{ll}\text { - } & \text { Instrumen justifikasi } \\
\text { terhadap ketaatan } \\
\text { pada hukum formal. } \\
\text { - } & \text { Menghindari penyim- } \\
\text { pangan dan Konsistensi } \\
\text { pada ketentuan hukum } \\
\text { formal. } \\
\text { - Hakim sbg terompet } \\
\text { UU. }\end{array}$ & $\begin{array}{l}\text { - Instrumen justifikasi } \\
\text { moral terhadap } \\
\text { keta-atan pada } \\
\text { substansi hukum. } \\
\text { Melahirkan moral } \\
\text { substantif. } \\
\text { Menghindari pe- } \\
\text { n y i m p a n a n } \\
\text { dan Konsistensi } \\
\text { substansi hukum. } \\
\text { Diskresi sesuai } \\
\text { subs-tansi hukum. } \\
\text { Hakim tidak sekedar } \\
\text { terompet UU. }\end{array}$ & $\begin{array}{ll}\text { - } & \text { Instrumenmoral refleksif } \\
\text { terhadap ketaatan pada tujuan } \\
\text { dan proses. } \\
\text { - } \quad \text { Merefleksikan nilai-nilai moral. } \\
\text { - } \quad \text { Menghindari penyim-pangan } \\
\text { dan Koheren pada tujuan dan } \\
\text { proses. } \\
\text { - Diskresi lebih substantif dan } \\
\text { filosofis sesuai tujuan dan } \\
\text { hasil. } \\
\text { - Hakim sbg terompet hukum } \\
\text { dan keadilan. }\end{array}$ \\
\hline DOKTRIN & 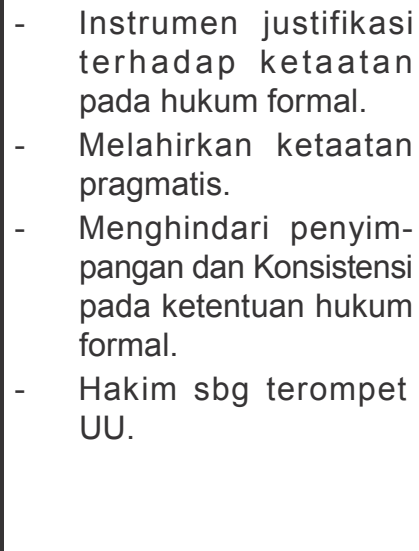 & 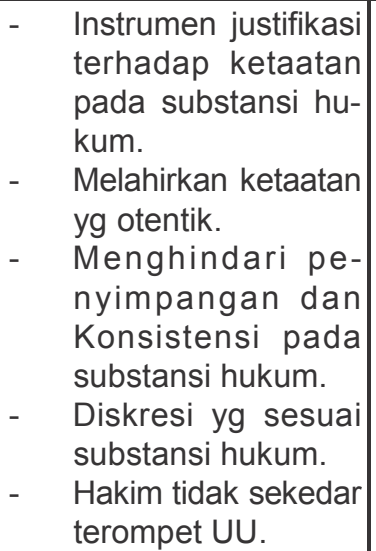 & 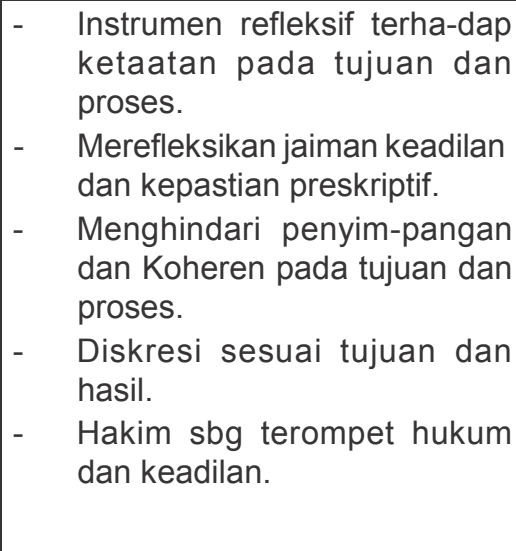 \\
\hline
\end{tabular}

Berdasarkan gambaran tentang hubungan fakta, norma, moral dan doktrin terhadap pertimbangan putusan hakim di atas, maka hendaknya semua komponen dan proses pengakan hukum di arahkan pada tipe rasionalitas hukum yang reflektif guna meningkatkan kualitas penegakan hukum dan dunia peradilan di tanah air.

Pandangan ini sejalan dengan pandangan Oliver Wendell Holmes dalam (L.B. Curzon, 1979) yang terkenal dengan sebutan "the great dissenter justice" yang melahirkan konsep yang dikenal dengan sebutan "the concept of clear and present danger". Holmes mengingatkan para hakim untuk tidak terpaku dan taqlid pada sistem "presedent" yang kaku, deterministik dan legalistik, tetapi hakim harus melihat realitas hukum yang hidup dalam masyarakat, dan bukannya bertumpu pada perundang-undangan yang merupakan ciptaan manusia biasa, yang juga tidak pernah sempurna, tidak lengkap dan senantiasa menuntut interpretasi dari para penegak hukumnya. Oleh karena itu, Bagi Holmes, yang ia anggap sebagai hukum adalah ramalan tentang apa yang akan dilakukan oleh pengadilan di dalam kenyataannya, dan tidak ada yang lebih penting daripada itu (the prophecies of what the courts will do in fact, and nothing more pretentious, are what I mean by the law). Bahkan menurut Holmes, hakim dalam membuat putusan selalu memasukkan suatu pertimbangan pribadi yang extra-legal sifatnya agar keputusan-keputusan yang dibuatnya lebih 
fungsional bagi kehidupan masyarakat, maka pengalaman yang tersimak dalam kehidupan akan lebih cermat menduga arah keputusan hakim daripada sekadar logika-logika hukum, "the live of the law has not been logic but experience".

\section{d. Penutup}

Dalam konteks penegakan hukum, hubungan antara fakta, norma, moral, dan doktrin hukum dalam pertimbangan putusan hakim -baik secara sendiri-sendiri, maupun bersama-sangat terkait atau korelatif satu sama lain. Putusan hakim harus merefleksikan komponen-komponen tersebut. Putusan Hakim yang dipertanggung jawabkan secara ilmiah adalah yang memenuhi persyaratan utama seperti yang diajarkan oleh Josef Esser, yaitu sistem konsisten dan adil utamanya mewujudkan Law and Legal reform.

Disamping hal - hal yang bersifat materiil korporil, banyak dan beraneka ragam ganggguan dan motif-motif irrasionil yang dapat menyebabkan putusan Hakim menjadi sine lege ( tanpa berdasakan undang - undang ). Adapun yang dimaksudkan motif - motif irrasionil, gangguan tersebut ialah antara lain : egoisme, haus kekuasaan, loba tamak, kebodohan, purbasangka, kemunafikan, kecanduan budaya konsumerisme dan supplaierisme.

Apabila putusan hakim yang tidak memperhatikan fakta hukum sesungguhnya bukan putusan pengadilan. Demikian pula, putusan hakim yang tidak memperhatikan norma adalah kesewenang-wenangan. Putusan hakim yang tidak mengindahkan moral sesungguhnya gagal dari aspek pertanggungjawaban moral. Sedang putusan hakim yang tidak memuat doktrin hukum maka sesungguhnya putusan tersebut telah kehilangan arah (lose of direction). Dengan demikian, baik fakta hukum, norma, moral maupun doktrin hukum sesungguhnya merupakan instrumen otentik bagi hadirnya putusan hakim yang baik. Instrumen tersebut merupakan "conditio sine qua non" bagi putusan hakim yang meneguhkan rasa keadilan masyarakat (sense of justice).

Ditinjau dari perspektif rasionalitas hukum, putusan hakim dan hubungannya dengan fakta, norma, moral, dan doktrin dapat diklasifikasi ke dalam tiga tipe rasionalitas hukum, yaitu rasionalitas formal, rasionalitas substantif, dan rasionalitas refleksif. Masing-masing tipe rasionalitas hukum menggambarkan status dan kedudukan fakta, norma, moral dan doktrin dalam hubungannya dengan putusan hakim. Pola hubungan yang berlangsung saat ini masih didominasi tipe rasionalitas hukum formal. Ke depan -dalam rangka "good court governance"pengembanan hukum praktis hendaknya di arahkan ke tipe rasionalitas refleksif, minimal diupayakan menggeser pola hubungan tersebut dari tipe rasionalitas formal ke rasionalitas substantif dan pada saatnya ke arah tipe rasionalitas hukum refkleksif.

\section{Referensi}

Achmad Ali, 2008, Menguak Tabir Hukum, Edisi Kedua, Ghalia Indonesia, Jakarta.

Bruggink, J.J.H., 1996, Refleksi Tantang Hukum (Pengertian-pengertian Dasar Dalam Teori Hukum), Alih Bahasa Arief Sidharta, PT Citra Aditya Bakti, Bandung.

Curzon, L.B., 1979, Jurisprudence, M\&E Handbooks, Estover, Plymouth.

Haq, Hayyan UI, Mafia Peradilan Vs Law Society, Dalam Harian Kompas, Rabu, 19 Oktober 2005.

Komisi Yudisial, 2012, Laporan Utama dalam Buletin Komisi Yudisial, vol. vlI, No.2, September-Oktober, 2012.

Mertokusumo, Sudikno, 1985, Hukum Acara perdata Indonesia, Edisi Kedua, Liberty, Yogyakarta.

Satjipto Rahardjo, 2000, IImu Hukum, Cetakan ke-v, PT Citra Aditya Bakti, Bandung.

Teubner, Gunther, 1983, Substantive and Reflexive Elements in Modern Law, dalam Law and Society Review, volume 17, Nomor 2. 